\title{
Raising the minimum age of criminal responsibility in Scotland: law reform at last?
}

\author{
ELAINE E SUTHERLAND*
}

\author{
University of Stirling, Scotland, and Lewis and Clark Law School, \\ Portland, Oregon
}

\begin{abstract}
Children in Scotland are held criminally responsible from the age of 8 , something that has attracted wholly justified criticism within the country and from international organisations, including the UN Committee on the Rights of the Child. Despite the fact that this puts Scots law in the same camp as some of the world's least progressive regimes, proposals to raise the minimum age of criminal responsibility have, to date, been rejected. For the second time this century, a government-appointed advisory group recently recommended raising the age to 12 .

Setting the minimum age of criminal responsibility in Scotland in the context of historical, international and comparative developments and the burgeoning contemporary literature, this article argues that the climate for change has never been better. It predicts that, this time, the advisory group's recommendation will result in legislative reform and highlights the challenges that will result.
\end{abstract}

\section{Introduction}

A ny discussion of juvenile justice in Scotland tends to focus on the children's hearings Asystem, an approach that was regarded as particularly ground-breaking when it was introduced in 1971 and continues to attract approval. The hearings system takes a holistic approach to the needs of both victimised and troublesome children and young people, offering supportive, non-punitive measures, premised on what will serve the welfare of the child, where intervention is required. While the hearings system has undergone reform over the years, safeguarding and promoting the child's welfare remains at its core.

Yet, alongside this picture of enlightenment, the minimum age of criminal responsibility in Scotland remains 8 years old, often described as being the lowest in Europe, ${ }^{1}$ putting Scotland in the same camp as some of the world's least progressive legal systems. It is no surprise that this has attracted criticism within the country and from bodies no less august than the UN Committee on the Rights of the Child and the UN Committee on Human Rights.

* Professor of Child and Family Law, Stirling Law School, and Distinguished Professor of Law, Lewis and Clark Law School.

1 This description is not wholly accurate since a number of European countries, including France and Luxembourg, have no stated minimum age. See, Don Cipriani, Children's Rights and the Minimum Age of Criminal Responsibility: A Global Perspective (Ashgate 2009) ch 5. 
In its most recent Concluding Observations, the UN Committee on the Rights of the Child again criticised the low age of criminal responsibility throughout the UK but, this time, it emphasised the positive, with the words:

The Committee notes that the Scottish government is open to raising the minimum age of criminal responsibility and that an Advisory Group was established to explore these issues and develop recommendations for consultation. $^{2}$

That advisory group recommended raising the age of criminal responsibility to $12^{3}$ and, in response, the Scottish government undertook a public consultation on the matter. There has been widespread support for the recommendation, certainly from the legal profession, children's rights groups and academics. But we have been here before, only to find the prospect of reform coming to nought. This article examines the minimum age of criminal responsibility in Scotland in the context of historical, international and comparative developments and the burgeoning contemporary literature. It argues that the climate for change has never been better and predicts that, this time, the law will be reformed, but warns that there are consequential challenges still to be addressed.

\section{The story so far}

When viewed from a contemporary perspective, the adult criminal justice system of previous ages, with its emphasis on physical punishment, transportation and capital sentences, seems barbaric. Indeed, it was. Yet, that system provides the context in which juvenile justice of the time must be understood. Thus, it is somewhat heartening to find that, when the Scottish institutional writers from the seventeenth century onwards explored the different treatment of juveniles, they addressed issues that the modern reader would recognise as being at the heart of the current debate on criminal responsibility: the capacity of children to understand the wrongfulness of the act; ${ }^{4}$ their opportunity to make choices; their ability to instruct a defence and, thus, secure a fair trial; and the relevance of age in sentencing. The fascinating nuances of their deliberations are discussed elsewhere and need not detain us. ${ }^{5}$ For our present purpose, it is enough to know that, in Scotland, children below the age of 7 years old were regarded as incapable of crime'. ${ }^{6}$ Minor children, being those between the ages of 7 and 14, were generally thought to be exempt from capital punishment ${ }^{7}$ and there are numerous examples of 'leniency' being shown in sentencing on account of the minority of the offender. ${ }^{8}$

2 UN Committee on the Rights of the Child, Concluding Observations on the Fifth Periodic Report of the UK of Great Britain and Northern Ireland CRC/C/GBR/CO/5, 3 June 2016, para 77.

3 The Report of the Advisory Group on the Minimum Age of Criminal Responsibility (The Scottish Government 2016) 11.

4 Sir George Mackenzie, The Laws and Customs of Scotland in Matters Criminal (first published 1678, 2nd edn 1699, Lawbook Exchange 2005)) I, I, 7.

5 For an excellent discussion, see Claire McDiarmid, Childhood and Crime (Dundee University Press 2007) ch 5.

6 Archibald Alison, Principles of the Criminal Law of Scotland (first published 1832, Law Society of Scotland and Butterworths 1989) 666. David Hume made the same point in his Commentaries on the Law of Scotland Respecting Crimes (first published 1819: Law Society of Scotland 1986) i, 35.

7 Hume was unwilling to elevate this idea to one of general principle irrespective of 'how deliberate soever the wickedness, or how incorrigible the obstinacy, or how cunning the malice of the offender': Hume (n 6) i, 34.

8 'Leniency' too must be understood in the context of the time and Hume (n 6), 32-34, includes the following examples: Duff and Millar, March 1701 (two boys aged 14 and 12, convicted of housebreaking along with an adult, were sentenced to be scourged at the gibbet while the adult was sentenced to death); Alexander Livingston, 1749 (a 12-year-old boy convicted of killing another boy by stabbing him was sentenced to transportation); and Mair and Atchieson, 25 March 1818 (two boys of 15 who were convicted of housebreaking and sentenced to death had their sentences reduced to transportation). 
While separate juvenile courts were established by the Children Act 1908, the minimum age of criminal responsibility remained untouched until 1928, when the first separate Scottish inquiry into the care and protection of children and the treatment of juvenile offenders reported. ${ }^{9}$ It recommended raising the minimum age of criminal responsibility to $8 .{ }^{10}$ The report gives only a brief explanation for this very minor change and one is left with the impression that the Committee would have liked to raise the age further. It may have been that it, like so many similar bodies since, was conscious of what would be politically acceptable. In any event, its recommendation was implemented. ${ }^{11}$ Parallel developments took place in England and Wales, ${ }^{12}$ with the minimum age of criminal responsibility there being raised further, to 10 years old, in 1963.13 There was no equivalent development in Scotland and it was at this time that the juvenile justice systems in the two jurisdictions began to diverge.

The children's hearings system was introduced in Scotland in $1971^{14}$ and was based on the recommendations of the Kilbrandon Report of $1964 .{ }^{15}$ Fundamental to these recommendations was a belief that the needs of children who offended were much the same as those of abused or neglected children since, in each case, 'the normal up-bringing process' had 'fallen short'. ${ }^{16}$ Thus, it was appropriate to deal with them in the same tribunal. A second strand of the Kilbrandon philosophy was that, while courts were the appropriate place to determine disputed facts, decisions about what should happen to the child thereafter could be dealt with by panels of trained lay people. In all of this, the goal of the hearings system was (and remains) to find a positive way forward on the basis that the child's welfare is the paramount consideration. ${ }^{17}$

In contrast to the adult criminal justice system, the Kilbrandon approach to juvenile offenders prioritised prevention, education and treatment and that goes a long way to explaining the Committee's views on the age of criminal responsibility. ${ }^{18}$ It emphasised the function of the minimum age, in the past, as a device that protected the young from harsh punishment, including the death penalty. However, if offenders were to be treated rather than punished, then the whole notion of criminal responsibility became less important. ${ }^{19}$ The Committee was also troubled by the lack of scientific evidence on when

9 Report of the Departmental Committee on Protection and Training (HMSO 1928) (Morton Committee).

10 Ibid 48.

11 Children and Young Persons (Scotland) Act 1932, s 14.

12 Report on the Treatment of Young Offenders (Cmnd 2831 HMSO 1927) (Molony Committee), leading to the Children and Young Persons Act 1932, s 19.

13 Children and Young Persons Act 1963, s 16.

14 Social Work (Scotland) Act 1968. A brief explanation of the system can be found in Elaine E Sutherland, Family Law Basics 3rd edn (W Green 2014) ch 7. For a more detailed treatment, see Kenneth McKNorrie, Children's Hearings 3rd edn (W Green 2013).

15 Report of the Committee on Children and Young Persons, Scotland (Cmnd 2306 HMSO 1964) (Kilbrandon Committee), known as the 'Kilbrandon Report' or simply 'Kilbrandon'.

16 Ibid para 15.

17 The hearings system is now governed by the Children's Hearings (Scotland) Act 2011 (the 2011 Act) and s 25 ascribes paramountcy to safeguarding and promoting the welfare of the child throughout childhood. While taking account of any views the child wishes to express was always inherent in children's hearings, the obligation to do so is now articulated expressly in the statute: 2011 Act, s 27.

18 Kilbrandon Report (n 15) para 54.

19 Ibid para 64. 
responsibility could be ascribed to the young. ${ }^{20}$ All of that led it to conclude that "the age of criminal responsibility" is largely a meaningless term'. ${ }^{21}$

Like all such exercises, the Kilbrandon Report was a product of its time. While the 'treatment' or 'welfare' model of juvenile justice has been subject to later criticism, ${ }^{22}$ it passed largely unremarked at the time in Scotland. ${ }^{23}$ As we shall see, there is now solid neuro-scientific evidence that provides valuable insights into the capacity of young people for impulse control and decision-making. ${ }^{24}$ It is also worth bearing in mind that the Kilbrandon Committee's deliberations took place before the International Covenant on Civil and Political Rights and the UN Convention on the Rights of the Child (UNCRC) created international obligations in terms of the minimum age of criminal responsibility. ${ }^{25}$

In the event, the Kilbrandon Committee's antipathy towards a minimum age of criminal responsibility had no impact. The concept remained part of Scots law, the relevant age continued to be 8 and the distinction between civil and criminal law was retained within the hearings system when it came to proving the facts on which a referral was based. Before a child can be referred to a children's hearing, two criteria must be satisfied: there must be a prima facie case indicating that the child comes within the scope of at least one of the 17 grounds listed in the statute ${ }^{26}$ and it must be determined that a compulsory supervision order is necessary. ${ }^{27}$ Most of the grounds for referring a child to a hearing focus on protecting children from abuse or neglect or from adults who may pose a threat to them, while several address behaviour by the child that is cause for concern. ${ }^{28}$ Where the child is 8 or older, he or she may be referred to a children's hearing on the ground that 'the child has committed an offence'. ${ }^{29}$ If the child or any of the 'relevant persons' (usually the child's parents) do not accept that the allegations supporting the ground on which the child has been referred to a hearing are true, ${ }^{30}$ the matter must be proven in court. Proof is on the balance of probabilities in all cases except for the offence ground, when proof beyond reasonable doubt is required, as is the norm in criminal cases in Scotland. ${ }^{31}$

20 Ibid.

21 Ibid para 65.

22 Anthony M Platt, The Child Savers: The Invention of Delinquency (University of Chicago Press 1977). For a discussion of the unfounded promises of the welfare approach, see Gault v United States 387 US 1 (1976).

23 For an early exception, see John P Grant, 'The Children's Hearings System in Scotland: Its Strengths and Weaknesses' (1975) 10 Irish Jurist 23.

24 See nn 109-12 and the accompanying text below.

25 See nn 52-65 and the accompanying text below.

26 Children's Hearings (Scotland) Act 2011, s 67(2).

27 Ibid s 66(2).

28 These include: 'the child has misused' alcohol or drugs; 'the child's conduct has had, or is likely to have, a serious adverse effect on the health, safety or development of the child or another person'; 'the child is beyond the control of a relevant person' (usually, a parent); and 'the child has failed without a reasonable excuse to attend at school regularly'.

292011 Act, s 67(2)(j).

30 While legal aid is available to children in limited circumstances, most children are not represented at hearings and it is not known how often a child accepts the grounds for any number of very poor reasons: to please the panel members, to please his or her parents or simply to get the whole thing over with.

312011 Act, s 101(3). 
The minimum age of criminal responsibility was not revisited until after the creation of the Scottish Parliament ${ }^{32}$ when an advisory group established to examine the matter recommended raising the age to 12.33 The timing of that recommendation could not have been worse since it coincided with the emergence of a 'tough on crime' agenda throughout the UK and further afield. In the USA, an increase in juvenile crime during the 1980 s and a series of highly publicised school shootings prompted John DiIulio to introduce the world to the notion of the 'juvenile super-predator'. ${ }^{34}$ The 1993 murder of James Bulger by two 10-year-olds, in England, had a significant impact on public perceptions of juvenile offending throughout the UK. ${ }^{35}$ The dominant thinking is indicated by the title of the Home Office report that heralded the abolition of the doli incapax presumption in England and Wales: 36 No More Excuses: A New Approach to Tackling Youth Crime in England and Wales. 37

The rhetoric in Scotland was similar and, while the children's hearings system remained intact, mandatory parenting classes and antisocial behaviour orders were introduced. ${ }^{38}$ The political climate was simply not conducive to raising the minimum age of criminal responsibility and the Labour administration of the day diverted calls to implement the recommendation of the advisory group it had established by referring the matter to the Scottish Law Commission. The Commission attributed two distinct meanings to the term 'minimum age of criminal responsibility'. The first meaning - and, it must be said, the way the term was at the time and remains generally understood in Scotland ${ }^{39}$ - denotes the age below which a child could not be regarded as capable of offending. The second meaning - and the one the Commission preferred - is the age below which a child is immune from prosecution in a criminal court. ${ }^{40}$

Having shifted the focus from capacity to process, the Commission made only passing reference to the emerging scientific evidence, indicating that it was 'not in any sense making any judgment on the validity or importance of work done by experts in the field

32 Scotland Act 1998.

33 Report of Advisory Group on Youth Crime (Scottish Executive 2000).

34 John J DiIulio Jr, 'The Coming of the Super-Predators' Weekly Standard (Washington DC 27 November 1995) 24: 'On the horizon . . . are tens of thousands of severely morally impoverished juvenile super-predators. They are perfectly capable of committing the most heinous acts of physical violence for the most trivial reasons . . . They fear neither the stigma of arrest nor the pain of imprisonment. They live by the meanest code of the meanest streets, a code that reinforces rather than restrains their violent, hair-trigger mentality.' He later expressed regret over his predictions and their impact: Elizabeth Becker, 'As Ex-Theorist on Young “Superpredators,” Bush Aide Has Regrets' New York Times (New York 9 February 2001).

35 Thomas Crofts, 'Catching up with Europe: Taking the Age of Criminal Responsibility Seriously in England' (2009) 17(4) European Journal of Crime, Criminal Law and Criminal Justice 267, 274; Enys Delmage, 'The Minimum Age of Criminal Responsibility: A Medico-Legal Perspective’ (2013) 13(2) Youth Justice 102, 103; Heather Keating, 'The "Responsibility' of Children in the Criminal Law' (2007) 19(2) Child and Family Law Quarterly 183, 198; Alex Newbury, 'Very Young Offenders and the Criminal Justice System: Are We Asking the Right Questions?' (2011) 23(1) Child and Family Law Quarterly 94, 94.

36 Crime and Disorder Act 1998, s 34. The presumption placed the burden on the prosecution to prove that a young person between the ages of 10 (the minimum age of criminal responsibility) and 14 understood the difference between right and wrong at the time of the offence.

37 White Paper (Cm 3809 Home Office 1997).

38 Claire McDiarmid, 'Juvenile Offending: Welfare or Toughness' in Elaine E Sutherland, Kay E Goodall, Gavin F M Little and Fraser P Davidson, Law Making and the Scottish Parliament: The Early Years (Edinburgh University Press 2011).

39 Gerald H Gordon, The Criminal Law of Scotland 3rd edn, Michael G A Christie (ed) (W Green 2000) para 8.28: a 'person under the age of criminal responsibility cannot commit any offence'.

40 Scottish Law Commission, Discussion Paper on the Age of Criminal Responsibility (Discussion Paper 115 Scottish Law Commission 2001) para 2.2. 
of child development and educational psychology'. ${ }^{41}$ It recommended that, 'any rule (whether at common law or statutory) on the age at which children cannot be found guilty of an offence should be abolished' 42 and that children below the age of 12 should be exempt from prosecution, with it being competent to refer their cases to a children's hearing instead. ${ }^{43}$

Meanwhile, a group of respected scholars produced A Draft Criminal Code for Scotland, which contained the provision: 'A person is not guilty of an offence by reason of anything done when the person is or was a child under twelve years of age. ${ }^{44}$ In the commentary portion of the Draft Code, they explain that this is a matter of criminal responsibility rather than just a matter of temporary protection from prosecution'. ${ }^{45}$

In the event, the legislation that emerged favoured the Commission's position, but did not follow its recommendations in full. First, the minimum age of criminal responsibility was not abolished and remains 8 years old. ${ }^{46}$ Secondly, while statute now prohibits the prosecution of anyone below the age of 12, it makes clear (unlike the Commission's version and taking the views of the drafters of the Code on board) that a person may not be prosecuted in respect of anything done before reaching that age. ${ }^{47}$ Thus, a prosecutor cannot simply wait until the child's 12th birthday and then prosecute him or her for something that the child did as a 10 -year-old.

Lobbying for reform of the minimum age of criminal responsibility continued, with the issue being raised during the passage of the Children's Hearings (Scotland) Act 2011 and the Children and Young People (Scotland) Act 2014 - all to no effect. That, then, is the background: a catalogue of varied approaches to the minimum age of criminal responsibility in Scotland with recommendations for reform being largely ignored by legislators.

There was another moment of false hope when a Liberal-Democrat Member of the Scottish Parliament proposed an amendment to what became the Criminal Justice (Scotland) Act 2016 that would have raised the minimum age of criminal responsibility to 12. ${ }^{48}$ The amendment failed but, with an election in prospect, the majority Scottish Nationalist Party (SNP) administration was keen to demonstrate that it was 'listening' and it set up another advisory group to review the matter. That advisory group, like its 2000 predecessor, recommended raising the minimum age of criminal responsibility to 12.49

At the time of writing, the SNP administration (now, a minority government) has just completed a public consultation on the recommendation. ${ }^{50}$ The Faculty of Advocates and the Law Society of Scotland, representing the two branches of the legal profession

41 Ibid para 3.27.

42 Scottish Law Commission, Report on the Age of Criminal Responsibility (Scot Law Com No 185, 2002) rec 1.

43 Ibid recs 2 and 3.

44 Eric Clive, Pamela Fergusson, Christopher Gane and Alexander McCall Smith, A Draft Criminal Code for Scotland with Commentary (Scottish Law Commission 2003) s 15.

45 Ibid 42.

46 Criminal Procedure (Scotland) Act 1995, s 41.

47 Criminal Procedure (Scotland) Act 1995, s 41A, added by the Criminal Justice and Licensing (Scotland) Act 2010, s 52(2).

48 Elaine E Sutherland, 'Time to Raise the Age of Criminal Responsibility' (2015) Journal of the Law Society of Scotland Online (uploaded 14 September 2015) <www.journalonline.co.uk/Magazine/60-9/1020694.aspx>.

49 Report of the Advisory Group on the Minimum Age of Criminal Responsibility (n 3) 11.

50 Consultation on the Minimum Age of Criminal Responsibility (Scottish Government 2016): <https://consult.scotland.gov.uk/youth-justice/minimum-age-of-criminal-responsibility>. 
in Scotland, have expressed their support for raising the minimum age of criminal responsibility in Scotland to 12, as have numerous children's rights groups and academics. ${ }^{51}$ Thus, the stage is set, once again, for legislation to implement the recommendation. The desirability of this course of action becomes all the more apparent when one examines the international norms, comparative position and scholarly research on the issue.

\section{International norms and the comparative position}

The last 30 years have seen enormous strides in international recognition of the special position of children and of their rights. Numerous international and regional instruments address juvenile justice, often dealing expressly with the minimum age of criminal responsibility, ${ }^{52}$ and a number of instruments are of particular significance in Scotland.

While the International Covenant on Civil and Political Rights ${ }^{53}$ does not mandate the provision of a minimum age of criminal responsibility, its monitoring body, the UN Human Rights Committee, proceeds on the basis that such an obligation exists. Thus, in its most recent Concluding Observations on the UK, it criticised the low age throughout the country, mentioning Scotland expressly, and urged raising the minimum age of criminal responsibility 'in accordance with international standards and ... [ensuring] . . the full implementation of international standards for juvenile justice'. 54

As might be expected, the $\mathrm{UNCRC}^{55}$ addresses the minimum age of criminal responsibility, but it is rather less directive on this issue than it is on many others. In contrast to numerous articles providing that 'States Parties shall [do X]', Article 40(3) is in the following terms:

States Parties shall seek to promote the establishment of laws, procedures, authorities and institutions specifically applicable to children alleged as, accused of, or recognized as having infringed the penal law, and, in particular:

(a) the establishment of a minimum age below which children shall be presumed not to have the capacity to infringe the penal law. ${ }^{56}$

The explanation for this rather insipid provision lies in its history. While juvenile justice was discussed early on during the 10-year process of drafting the UNCRC, there was initially no mention of a minimum age of criminal responsibility. ${ }^{57}$ It was not until the Technical Review, in 1988, that the issue was addressed at all when the Centre for Social

51 At the time of writing, the responses are available only in anonymised, uncollated form: $<$ https://consult.scotland.gov.uk/youth-justice/minimum-age-of-criminal-responsibility $>$. The response of the Faculty of Advocates can be found on its website: <www.advocates.org.uk/news-andresponses/responses/2016/jun/the-minimum-age-of-criminal-responsibility>; with that of the Law Society of Scotland being on its website: <www.lawscot.org.uk/media/860539/crim-fam-minimum-age-of-criminalresponsibility-consultation-response-final-.pdf $>$.

52 For a discussion of the various instruments, see, Cipriani (n 1) ch 3.

53 International Convention on Civil and Political Rights, 999 UNTS 171, adopted 16 December 1966, entered into force 3 January 1976.

54 UN Human Rights Committee, Concluding Observations on the Seventh Periodic Report of the UK of Great Britain and Northern Ireland CCPR/C/GBR/CO/7, 17 August 2015, para 23.

55 UNCRC, 1577 UNTS 3, adopted 20 November 1989, entered into force 2 September 1990.

56 Emphasis added.

57 Save the Children Sweden and the Office of the UN High Commissioner for Human Rights, Legislative History of the Convention on the Rights of the Child vol II (UN High Commissioner for Human Rights 2007) 738-74. What became Articles 37 and 40 started life as a single article, initially Article 20, then Article 19, being bifurcated during the second reading stage. 
Development and Humanitarian Affairs called for a number of provisions contained in the Beijing Rules, ${ }^{58}$ adopted only three years earlier at the Seventh UN Congress, to be incorporated. ${ }^{59}$ Thereafter, the rather equivocal and lacklustre text of rule $4.1^{60}$ of the Beijing Rules was used in the UNCRC deliberations and Article 40 continues its failure to provide for a specific minimum age of criminal responsibility.

In contrast to the drafters of the UNCRC, the UN Committee on the Rights of the Child has taken a more focused and directive approach to the matter. After an abortive attempt in 2002, it produced General Comment No 10: Children's Rights and Juvenile Justice, ${ }^{61}$ in 2007, where it noted the varied approach of states parties to the minimum age of criminal responsibility. However, it made its own position abundantly clear when it described the ages as ranging 'from a very low level of age 7 or 8 to the commendably high level of 14 or $16^{\prime 62}$ and found that setting the age below 12 'not to be internationally acceptable'. ${ }^{63}$ Each of the Concluding Observations on the UK and Northern Ireland that preceded General Comment No 10 and those that came later have criticised the low age of criminal responsibility throughout the country, ${ }^{64}$ with the UN Committee on the Rights of the Child indicating, yet again, in 2016, that it was 'concerned' that the 'minimum age of criminal responsibility remains 8 years of age in Scotland'. 65

Given its vintage and history, it is not surprising to find that the European Convention on Human Rights makes no express reference to juvenile offenders, far less to a minimum age of criminal responsibility. However, the European Court of Human Rights has made a significant contribution on the issue of age in the context of the fair hearing requirements of Article 6. In $T v U K$ and $V v U K^{66}$ it considered the trial, in England, of Robert Thomson and Jon Venables who, it will be remembered, were 10 years old when they killed 2-year-old James Bulger. Special arrangements, designed to accommodate their youth, were made at the trial and they were legally represented. However, the European Court concluded that, by virtue of their ages and states of mind, they were unable to participate effectively in the proceedings and, thus, had been denied the right to a fair

58 UN Standard Minimum Rules for the Administration of Juvenile Justice A/RES/40/33, 29 November 1985, known as the Beijing Rules.

59 In its submission, the Centre's Social Development Division reminded the drafters that 'it should be clearly stated that there should be no criminal responsibility of children until they reach a certain age': Legislative History of the Convention on the Rights of the Child ( $\mathrm{n}$ 57) 753. The Centre's Crime Prevention and Criminal Justice Branch submitted a lengthy note referencing the Beijing Rules and repeated the need for a minimum age of criminal responsibility: ibid 759.

60 Rule 4.1 provides: 'In those legal systems recognizing the concept of the age of criminal responsibility for juveniles, the beginning of that age shall not be fixed at too low an age level, bearing in mind the facts of emotional, mental and intellectual maturity.'

$61 \mathrm{CRC} / \mathrm{C} / \mathrm{GC} / 10,25$ April 2007.

62 Ibid para 30 (emphasis added).

63 Ibid para 32.

64 Concluding Observation on the UK and Northern Ireland, 15 February 1995 CRC/C/15/Add 34, paras 40-43; Concluding Observation on the UK and Northern Ireland 9 October 2002, CRC/C/15/Add.188, paras 59 and 62; Concluding Observations of the Committee on the Rights of the Child on the UK of Great Britain and Northern Ireland CCR/C/GBR/CO/4, 3 October 2008, para 78.

65 Concluding Observations on the Fifth Periodic Report of the UK of Great Britain and Northern Ireland CRC/C/GBR/CO/5, 3 June 2016, para 77(a).

66 (2000) 30 EHRR 121. 
hearing, in breach of Article 6(1). ${ }^{67}$ Similarly, in $S C v U K,{ }^{68}$ the European Court concluded that an 11-year-old with a mental age of a 6-8 years old was unable to follow, or participate effectively in his trial and, again, it found a breach of Article 6(1).

The direction of international norms is clear: 12 is the minimum acceptable age at which to start attributing criminal responsibility. How, then, are other countries responding to these norms? International comparisons must be approached with a degree of caution, not least due to differences in terminology and the fact that the minimum age of criminal responsibility is only one part of the overall approach to juvenile justice. Nonetheless, insights can be gleaned from Don Cipriani's much-cited review of the minimum age of criminal responsibility in over 200 countries around the world. ${ }^{69}$ Published in 2009, his research revealed that some 23 countries had no stated minimum age of criminal responsibility, with the median age being 12 years old. ${ }^{70}$ European counties tend to favour 13 or 14, while the Scandinavian norm is 15 .

The comparative picture is not static and the Child Rights International Network ${ }^{71}$ reports that a small number of states have lowered the minimum age of criminal responsibility over the last few years or are considering doing so, albeit in no case was it actually reduced to below $12 .{ }^{72} \mathrm{It}$ is heartening to see, then, that a recent expert review of the most pressing issues facing vulnerable young people in New Zealand, commissioned by the Minister for Social Development, recommended raising the age of criminal responsibility from 10 to $12 .{ }^{73}$ By any measure, having 8 as the minimum age of criminal responsibility does not sit well alongside international and comparative norms.

\section{When do children acquire the capacity to offend?}

The emergence and development of international norms on juvenile justice have coincided with - and, undoubtedly, have prompted - an increase in research and publication in the field and scholars make frequent reference to these international efforts. While there have long been calls to raise the minimum age of criminal responsibility, the last two decades have witnessed a wealth of scholarly literature on the subject. It will be recalled that the Scottish Law Commission offered two interpretations of the term, distinguishing the age at which the capacity to form the necessary intention to offend is attributed to a child from the age below which the child is immune from prosecution. Most academics focus on the capacity of children and young people and the vast majority of academics who have contributed to the debate, both in Scotland and abroad, support a minimum age of criminal responsibility significantly higher than 8 years old.

Two elements must be present for the commission of a crime: the actor must form the requisite intention - the mens rea - and that must be accompanied by an act - the actus reus - prohibited by the criminal law. Forming the requisite intention requires the capacity

67 Ibid para 89.

68 (2005) 40 EHRR 10.

69 Cipriani (n 1) xiii.

70 Ibid 109. As Cipriani points out, the average age of 10 is not as useful a measure because the calculation is skewed by having to attribute 0 to the 23 countries with no stated age.

71 For updated information, see the Child Rights International Network website, Minimum Ages of Criminal Responsibility around the World < www.crin.org/en/home/ages>.

72 Child Rights International Network, States Lowering the Age of Criminal Responsibility $<$ www.crin.org/en/library/publications/juvenile-justice-states-lowering-minimum-age-criminalresponsibility $>$.

73 Expert Panel Final Report: Investing in New Zealand's Children and their Families (Rebstock Report) (Ministry of Social Development 2016) rec 60(g). 
to understand the wrongfulness and criminality of the act, combined with a meaningful opportunity and the ability to make choices.

\section{UNDERSTANDING}

Turning first to understanding the wrongfulness of the act, it is accepted that babes in arms have insufficient understanding to form the requisite intention. Thereafter, at what point in the maturation process do children acquire the necessary comprehension? That is a complex question and Claire McDiarmid summarises the various elements as including: knowledge of the difference between right and wrong and that the particular act in question is wrong; understanding that it is criminal and what that means; and the ability to place the act in a moral context. ${ }^{74}$

One way to evaluate a child's comprehension of these various facets is by means of an individual assessment. Indeed, there is a fundamental flaw in using a fixed age to determine capacity across the board since children and young people mature at different rates as a result of a host of genetic and environmental factors. On that basis, any blanket age, whether in the civil or criminal context, can be no more than an approximate - and, sometimes, inaccurate - cypher for meaningful assessment of actual capacity. A number of commentators resist having a fixed age of criminal responsibility for this reason and view a binary notion of capacity - one either has it or one does not - as an oversimplification that fails to embrace the evolving capacity of children. ${ }^{75}$ Individualised assessment is time-consuming and, thus, costly, and the attraction of a fixed age limit lies in it being cheap and administratively convenient. The potential for injustice is reduced if, as in Scottish criminal cases, it is open to the defence to show that, despite having reached the benchmark age, the child did not in fact have the requisite capacity to understand. ${ }^{76}$

At the heart of calls to raise the minimum age of criminal responsibility beyond 8 (or 10) years old lies the belief that children of that age simply do not understand the requisite elements of criminal activity sufficiently well for criminal responsibility to be attributed to them. ${ }^{77}$ Research by Glen Smith and Nick Winkfield concluded that: 'By the age of seven years, children are able to distinguish between right and wrong and seem to be aware of the criminal implications of their behaviour." 78 Unfortunately, the only

74 Claire McDiarmid, 'An Age of Complexity: Children and Criminal Responsibility in Law' (2013) 13(2) Youth Justice 145, 152.

75 Kate Fitz-Gibbon, 'Protection for Children before the Law: An Empirical Analysis of the Age of Criminal Responsibility, the Abolition of Doli Incapax and the Merits of a Developmental Immaturity Defence in England and Wales' (2016) 16(4) Criminology and Criminal Justice 391. See also, the 'capabilities approach' developed in Rosalind Dixon and Martha Nussbaum, 'Children's Rights and the Capability Approach: The Question of Special Priority’ (2011-2012) 97 Cornell Law Review 549. See further, Kathryn Hollingsworth, 'Theorising Children's Rights in Youth Justice: The Significance of Autonomy and Foundational Rights' (2013) 76(6) Modern Law Review 1046; Noam Peleg, 'Reconceptualising the Child's Right to Development: Children and the Capability Approach' (2013) 21 International Journal of Children's Rights 523; Dawn Watkins, 'Where Do I Stand? Assessing Children's Capacities under English Law' (2016) 28(1) Child and Family Law 25.

76 The press reported a Scottish case where the prosecutor decided not to proceed where the evidence demonstrated that an 11-year-old boy, originally charged with attempted murder, had a mental age below 8: Shirley English, 'Attempted Murder Dropped against Retarded Boy, 11' The Times (London 22 January 2001).

77 McDiarmid (n 74); Catherine Elliot, 'Criminal Responsibility and Children: A New Defence Required to Acknowledge the Absence of Capacity and Choice' (2011) 74(4) Journal of Criminal Law 289, 308.

78 Glen Smith and Nick Winkfield, The Development of the Moral Compass: A Study among Children Aged 7 to 16 in the UK (Youth Research Forum 2011) para 2.3.1. The same research found that 'as they get older they become more thoughtful and nuanced in their attitudes to moral questions'. 
report of the research on which these conclusions are based is described as a 'Summary' and, while it indicates that the findings resulted from an online, nationally representative, qualitative survey of 7507 - to 16-year-olds, there is little further information about the research methodology. In particular, the questions put to the children and young people are not disclosed. Distinguishing between right and wrong could mean appreciating, as one would expect of a 7-year-old, that certain behaviour meets with adult disapproval, but that could include anything from 'naughtiness' (being cheeky, telling fibs) to conduct that is actually criminal (stealing, killing and the like). That children 'seem to be aware' of the criminal implications of conduct is somewhat vague and, again, no information is provided about the depth or range of their comprehension. Thus, it would be a mistake to attach any great weight to this study.

The legal system's use of age limits is not confined to the criminal arena and many scholars point to the glaring inconsistency between the legal system's attribution of criminal responsibility at an early age and its recognition of the child's capacity as an actor or participant in other areas of the law. ${ }^{79}$ Heather Keating juxtaposes the capacity to consent to medical treatment and to participate in decision-making in the family law context, in England and Wales, ${ }^{80}$ with criminal responsibility, while Barry Goldson highlights the absurdity of regarding a child under 12 as too young to buy an animal companion, yet holding him or her criminally responsible. ${ }^{81}$

In Scotland, there are numerous inconsistent, age-related restrictions on accessing such rights and privileges as voting (16/18 years old), ${ }^{82}$ serving on a jury (18), 83 marrying or registering a civil partnership (16) ${ }^{84}$ and driving a motor vehicle $(16 / 17 / 18) .{ }^{85}$ The function of many age limits, like those on access to alcohol (18) 86 and gambling $(16 / 18),{ }^{87}$ is primarily protective. The trend with such protective regulation has been to increase the age limit, as occurred in respect of tobacco products when the age was raised from 16 to $18,{ }^{88}$ or to introduce new restrictions, like those on using tanning salons. ${ }^{89}$ As is often the case with statutory age limits, they vary, but the striking similarity between them is that they are significantly higher than 8 years old, the age of criminal responsibility. If the legal system regards children below the age of 16,17 or 18 as being

79 Delmage (n 35).

80 Keating (n 35).

81 Barry Goldson, "'Unsafe, Unjust and Harmful to Wider Society”: Grounds for Raising the Minimum Age of Criminal Responsibility in England and Wales' (2013) 13(2) Youth Justice 111, 120.

82 Voters in Westminster elections must be 18 years old: Representation of the People Act 1983, s 1. Sixteenyear-olds were first enfranchised across Scotland for the Scottish independence referendum: Scottish Independence Referendum (Franchise) Act 2013, s 2. They can now vote in elections to the Scottish Parliament and local authority elections: Scotland Act 1998, s 11, and the Scottish Local Government Elections Order 2011, SSI 2011/399, as amended most recently by the Scottish Local Government Elections Order 2016, SSI 2016/7.

83 Law Reform (Miscellaneous Provisions) (Scotland) Act 1980, s 1.

84 Marriage (Scotland) Act 1977, s 1, and Civil Partnership Act 2004, s 86, respectively.

85 Road Traffic Act 1988, s 101, with the minimum age depending on the type of vehicle.

86 Licensing (Scotland) Act 1976, s 68.

87 The age is generally 18, save when it comes to state-sanctioned gambling, with the age for participating in the National Lottery being 16: Betting Gaming and Lotteries Act 1963, s 21, the National Lottery etc. Act 1993, s 12 , and SI 1994/189.

88 Children and Young Persons (Scotland) Act 1937, s 18, as amended by the Smoking, Health and Social Care (Scotland) Act 2005 (Variation of Age Limit for the Sale of Tobacco Purchase and Consequential Modifications) Order 2007, SSI 2007/437.

89 Public Health, etc. (Scotland) Act 2008, ss 95-96. 
too immature to exercise the judgement necessary to participate in various activities or be exposed to particular dangers, how can it justify holding them criminally responsible?

This argument should be advanced with a degree of caution, particularly in the political arena, since it can be something of a double-edged sword. It could all too easily be employed to support the removal from children and young people of powers they now have, undermining their human rights. ${ }^{90}$ Conversely, demonstrating children's participatory capacity in the civil arena, particularly in Scotland where there is a very real attempt to embrace it, could be used to support a low minimum age of criminal responsibility. If children are capable of participating in decision-making from a young age, so the argument might go, then they can be held accountable in the criminal arena too.

However, a quick trip through the basics of the UNCRC and the relevant Scots law exposes any such argument for the fallacy that it is. At the heart of the UNCRC lies recognition of both the responsibility of the state and the adult world to protect children and young people and of their right to have their views taken into account. Article 3 prioritises the best interests of children, while Article 12 guarantees their participation rights, and both principles underpin the UNCRC as a whole. This is entirely consistent with the notion of the child's evolving capacity as articulated in Article 5.

Scots law provides a good example of real attempts to embrace these principles in the civil arena. Thus, those making decisions about children within the family, ${ }^{91}$ in the child protection context ${ }^{92}$ and in the courts ${ }^{93}$ are required to give the child the opportunity to express his or her views and to take account of these views in the light of the child's age and maturity. There is no minimum age for the exercise of participation rights, albeit that a child of 12 is presumed to have the requisite capacity to form a view. ${ }^{94}$ Similarly, children can consent to medical treatment or instruct a solicitor where the relevant professional determines that the child understands what is involved. ${ }^{95}$ The point is that children's agency is recognised in all of these situations, but they are not left wholly to their own devices since the safety net of adult involvement is there to mediate the final decision on the basis of the welfare principle. ${ }^{96}$

\section{THE OPPORTUNITY AND ABILITY TO MAKE CHOICES}

Forming criminal intent is not confined to comprehension since the actor must not only understand the nature of the conduct; he or she must also choose to act in a particular way. Inherent in that process is having the opportunity to make choices and the ability to exercise judgement. Children are impeded in their ability to make meaningful choices by their very position as children. They are subject to parental and other authority and have little control over their environment. ${ }^{97}$ There is an abundance of evidence demonstrating the nexus between offending, on the one hand, and neglect, deprivation and truancy, on

90 Goldson (n 81) 117.

91 Children (Scotland) Act 1995, s 6.

92 Ibid s 16(2) and Children's Hearings (Scotland) Act 2011, s 27.

93 Children (Scotland) Act 1995, s 11(7)(b).

94 Ibid ss 11(10) and 16(2) and Children's Hearings (Scotland) Act 2011, s 27(4).

95 Age of Legal Capacity (Scotland) Act 1991, s 2(4) and (4A).

96 The empowerment of children is arguably even greater in the context of adoption where a child of 12 or over can consent to, or veto, his or her own adoption, the child's consent not being subject to the power of the court to dispense with it as it can in respect of parental consent: Adoption and Children (Scotland) Act 2007, $\mathrm{s} 32$. Again, however, the court applies the welfare principle in approving adoptions.

97 Watkins (n 75) 27. 
the other, and the impact of these environmental factors can only undermine the child's autonomy. ${ }^{98}$

Ever since the (then) Minister for Children and Young People, Aileen Campbell, first expressed the Scottish government's 'ambition to make Scotland the best place in the world to grow up in', ${ }^{99}$ it has become a stock phrase in all government publications dealing with children. However, that laudable ambition is far from being realised for many children in Scotland. Poverty remains a significant problem. 100 According to the government's most recent figures, in 2014-2015, 22 per cent $(220,000)$ of Scotland's children were living in relative poverty ${ }^{101}$ and there are similarly disturbing statistics on children affected by homelessness ${ }^{102}$ and food insecurity. ${ }^{103}$ As at 31 July 2015, 15,404 children were classified as 'looked after', meaning that their care was subject to formal state oversight. ${ }^{104}$ While some 60 per cent of these children were living with their parents, other family members or friends, the remainder were in foster care or residential care. Deprivation impacts overall well-being and leads to social exclusion, poorer academic achievement, ${ }^{105}$ particularly for looked after children, ${ }^{106}$ and a sense of hopelessness amongst impoverished young people. ${ }^{107}$ Thus, it is illusory to suggest that these children have the opportunity to make meaningful choices.

What of the ability to exercise choice? Thomas Crofts analysed this decision-making process in terms of what he called the 'cognitive element', understanding the rules and the consequences of particular acts, and the 'volitional element', the ability to control one's actions. ${ }^{108}$ Enormous advances have been made by the neuro-scientific community in

98 Raymond Arthur, 'Rethinking the Criminal Responsibility of Young People in England and Wales' (2012) 20(1) European Journal of Crime, Criminal Law and Criminal Justice 13, 17-21; Elliot (n 77) 297.

99 Education and Culture Committee, Official Report 8 October 2013, col 2944 <http://www.scottish.parliament.uk/parliamentarybusiness /28862.aspx?r=8550\&mode=pdf $>$.

100 Peter Kenway, Sabrina Busche, Adam Tinson and Theo Barry Born, Monitoring Poverty and Social Exclusion in Scotland 2015 (Joseph Rowntree Trust 2015); Jim McCormick, A Review of Devolved Approaches to Child Poverty (Joseph Rowntree Trust 2013). See also the Child Poverty Action Group in Scotland website <www.cpag.org.uk/scotland>.

101 Poverty and Income Inequality in Scotland: 2014/2015 (Scottish Government 2016) 2.

102 In 2015-2016, while the overall number of people experiencing homelessness decreased, the number of households with children living in temporary accommodation rose by 8 per cent ( 209 households), with the number of children affected increasing by 13 per cent (591 children): Homelessness in Scotland 2015-2016 (Scottish Government 2016).

103 Filip Sosenko, Nicola Livingstone and Suzanne Fitzpatrick, Overview of Food Provision in Scotland (Scottish Government Social Research 2013).

104 Children's Social Work Statistics Scotland 2014/2015 (Scottish Government 2016).

105 Edward Sosu and Sue Ellis, Closing the Attainment Gap in Scottish Education (Joseph Rowntree Trust 2013), reporting that the gap between children from low-income and high-income households starts early and persists throughout childhood.

106 While the position has improved somewhat over the last five years, 'looked after children' (those under state jurisdiction) perform less well in education, are excluded from school more often (218 versus 27 per 1000) and are less likely to have a positive destination 9 months after leaving school (72 per cent versus 92 per cent) than pupils overall: Education Outcomes for Looked After Children 2014/2015 (Scottish Government 2016).

107 A report, based on interviews with 2311 16- to 24-year-olds from across the UK, found that 25 per cent of those from deprived homes believe that 'few' or 'none' of their career goals to be achievable, compared to 7 per cent of those from affluent families; one quarter of young people from poor homes (26 per cent) felt that 'people like them don't succeed in life'; and young people growing up in poverty are significantly less likely to imagine themselves buying a nice house or even finding a job in the future. See Prince's Trust, Broke, Not Broken (Prince's Trust and RBS 2011).

108 Thomas Crofts, 'Catching up with Europe' (2009) 17(4) European Journal of Crime, Criminal Law \& Criminal Justice 267, 286. 
understanding brain development, particularly in children and young people, and its impact on the decision-making process. In 2006, the Royal College of Psychiatrists reported:

Biological factors such as the functioning of the frontal lobes of the brain play an important role in the development of self-control and of other abilities. The frontal lobes are involved in an individual's ability to manage the large amount of information entering consciousness from many sources, in changing behaviour, in using acquired information, in planning actions and in controlling impulsivity. Generally the frontal lobes are felt to mature at approximately 14 years of age. ${ }^{109}$

A few years later, as part of an initiative to promote understanding of developments in neuro-science and their implications for society and public policy, the Royal Society published a number of well-referenced and accessible reports, including one dealing with Neuroscience and the Law. While warning that there is 'huge individual variability in the timing and pattern of brain development', it reported that changes in important neural circuits underpinning behaviour continue until at least the age of $20 .{ }^{110}$ Furthermore, rates of development for different regions of the brain impact the ability to moderate and regulate behaviour and 'may account for heightened emotional responses and the risky behaviour characteristic of adolescence'. ${ }^{111}$ Addressing the age of criminal responsibility in England and Wales, the Royal Society noted that, at the age of 10, the brain is developmentally immature and continues to undergo important changes linked to the regulation of behaviour, concluding that, from a neuro-scientific perspective, with regard to criminal responsibility, an arbitrary cut-off age may not be justifiable. ${ }^{112}$

In contrast to the scientific evidence, there is the realm of 'what everyone knows'. There is a view, in some quarters, that children are more mature now than in times past and that the minimum age of criminal responsibility should reflect the maturity of these savvy youngsters. This (mis)perception contributed to the abolition of the doli incapax presumption in England and Wales ${ }^{113}$ and played into the Scottish Law Commission recommendations in 2001. ${ }^{114}$ Most scholars refute this assertion ${ }^{115}$ and something of a lone voice amongst academics (but, sadly, not politicians and sections of the media) is that of Gerry Maher. It is worth remembering that he was a commissioner at the Scottish Law Commission when it recommended abandoning the concept of a minimum age of criminal responsibility altogether and his words echo the position taken there: essentially, that because children today understand technology in a way that was not open to children in centuries past, there may be a case for lowering the age of criminal responsibility. ${ }^{116}$

109 Royal College of Psychiatrists, Child Defendants Occasional Paper 56 (Royal College of Psychiatrists 2006) 38.

110 Brainwaves 4: Neuroscience and the Law (Royal Society 2012), 13 <https://royalsociety.org/ / media/Royal_Society_Content/policy/projects/brain-waves/Brain-Waves-4.pdf $>$.

$111 \mathrm{Ibid}$ 14. In terms of different regions of the brain developing at different times, it explained: 'The prefrontal cortex (which is especially important in relation to judgement, decision-making and impulse control) is the slowest to mature. By contrast, the amygdala, an area of the brain responsible for reward and emotional processing, develops during early adolescence.'

112 Ibid 14.

113 No More Excuses (n 37).

114 Scottish Law Commission (n 40) para 3.27: 'It could therefore be argued that there is a case for lowering the age of criminal responsibility to reflect the earlier maturity and understanding of children today as compared with children in 1932 [when the age was raised from 7 to 8].'

115 Arthur (n 98) 17-19; Keating (n 35) 195.

116 Gerry Maher, 'Age and Criminal Responsibility' (2004-2005) 2 Ohio State Journal on Criminal Law 493, 496. Compare with n 114, above. 
Yet, we live in a world of 'helicopter parents' and the sub-set, 'tiger moms'.117 Given the nexus between neglect, deprivation and offending, children who engage in criminal conduct may be less afflicted by this modern scourge than their more affluent peers. Nonetheless, it would be a mistake to confuse access to the internet and the attendant exposure to information (and misinformation) with the ability to make a considered judgement. ${ }^{118}$ Spending hours playing computer games, tweeting one's latest thoughts and believing that 'friends' are people who have clicked the requisite button on a Facebook page will not necessarily enhance the ability to function in the real world. More significantly, perhaps, 'what everyone knows' hardly compares with the neuro-scientific evidence on child development.

\section{Consequential challenges}

Raising the minimum age of criminal responsibility to 12 would be a welcome step, of course, but it is illusory to think that is an end of the matter because there are consequential challenges to be addressed. The reform, by itself, would not alter the conduct of children and young people and some 8 to 11-year-olds would continue to engage in behaviour that was previously criminal. In Scotland, the first issue, then, is whether the legal system has the tools necessary to address the behaviour. Rather more challenging is a second issue: how this, now non-criminal, conduct should be treated by the state when it gathers and retains information about individuals and subsequently discloses that information to third parties.

Supporters of raising the minimum age of criminal responsibility have never suggested that what was previously criminal conduct - what the 2016 advisory group called 'harmful behaviour' - by 8 to 11 -year-olds should simply be ignored. Indeed, if the child's actions suggest that there is cause for concern, then prioritising the child's welfare, as required by the UNCRC, mandates that it should be addressed.

Given the nexus between offending, on the one hand, and neglect, deprivation and truancy, on the other, ${ }^{119}$ it might be expected that a child referred to a children's hearing on offence grounds might just as easily be referred on care and protection or truancy grounds. Recent research bears out that expectation. ${ }^{120}$ A study of 1008 to 11 -year-olds alleged offenders in 2013-2014 found that only six of the cases resulted in a children's hearing. Of the six, four of the children were also referred on care and protection grounds, so their needs would have been addressed without the offence referral. Of the remaining two cases, one child denied the offence and, in the event, it was not established at proof. Thus, in only one case out of the 100 reviewed did the use of the offence ground prove crucial. Applying that result to all 215 of the 8 to 11 -year-old alleged offenders identified in the same year suggests that two or three such cases might arise annually. ${ }^{121}$

Even that figure may be an overestimate because it is possible that the children could be brought to a hearing on a care and protection ground. In recommending no change to

117 David Pimentel, 'Criminal Child Neglect and the "Free Range Kid": Is Overprotective Parenting the New Standard of Care?’ 2012 Utah Law Review 947.

118 June Ahn, 'The Effect of Social Network Sites on Adolescents' Social and Academic Development: Current Theories and Controversies' (2011) 62(8) Journal of the Association for Information Science and Technology 1435.

119 See the discussion at nn 98-107 and accompanying text, above.

120 Gillian Henderson, Indiya Kurlus and Gwen McNiven, Backgrounds and Outcomes for Children aged 8 to 11 Years Old Who Have Been Referred to the Children's Reporter for Offending (Scottish Children's Reporter Administration 2016).

121 SCRA Annual Report 2014/2015 (Scottish Children's Reporter Administration 2015). 
the grounds for referring a child to a children's hearing, the 2016 advisory group highlighted two of the existing grounds that might be particularly applicable to conduct that is currently treated as an offence: ${ }^{122}$ that 'the child's conduct has had, or is likely to have, a serious adverse effect on the health, safety or development of the child or another person' or that 'the child is beyond the control of a relevant person'. ${ }^{123}$

Was the advisory group correct in reaching this conclusion? One way to answer that question is by using a hypothetical example. Let us suppose that a 10 -year-old child, $\mathrm{X}$, burns down a school, causing the closure of the school and millions of pounds of damage. $\mathrm{X}$ is well cared for in a loving family and her parents had no reason to suspect that she would do this. While the school closure will create inconvenience and disadvantage to the other pupils, it is doubtful that it reaches the level of having the 'serious adverse effect' on them required to satisfy that ground of referral. Unless we are to interpret being 'beyond the control of a relevant person' as applying to all instances of a child doing something of which her parents disapprove, that ground would be ruled out as well.

Under the current system, X's conduct might well be addressed by voluntary measures short of a referral to a children's hearing and that could continue to be the case. However, what if X's parents are not willing to cooperate with any intervention? Another ground of referral - that 'the child is likely to suffer unnecessarily, or the health or development of the child is likely to be seriously impaired, due to a lack of parental care'124 - might apply. But what if the refusal of X's parents to cooperate is due to their belief that, as her parents, they are better placed to handle the situation? Arguably, it would be dangerously intrusive to treat any parental disagreement with a course of action suggested by the authorities as an indicator of neglect, a point highlighted recently by the Supreme Court. ${ }^{125}$ What if X's parents are willing to cooperate with voluntary measures, but $\mathrm{X}$ is not? In these circumstances, it would seem that nothing could be done to address the risk of X repeating her behaviour and compelling her to engage with intervention and support.

That example suggests that there may be a gap in the grounds of referral and that some 8 to 11-year-olds whose conduct would currently be treated as criminal, bringing them within the ambit of the hearings system, might fall through the cracks if the minimum age of criminal responsibility is raised to 12 . Doubtless, there are other examples. ${ }^{126}$ Happily, the problem can be remedied very easily by adding a ground along the lines that 'the child has caused serious damage to, or destruction of, property,' something that does not even require legislation since it can be done by Ministerial Order. ${ }^{127}$

The second issue arising from raising the minimum age of criminal responsibility gathering, retention and disclosure of information - presents rather more of a challenge in both conceptual and practical terms. Police Scotland, the single police authority created for the country when the various regional forces were unified, ${ }^{128}$ gathers rather a lot of

122 Report of the Advisory Group on the Minimum Age of Criminal Responsibility (n 3) paras 23-24.

123 Children's Hearings (Scotland) Act 2011, s 67(2)(m) and (n), respectively.

124 Ibid s 67(2)(a).

125 Christian Institute v Scottish Ministers [2016] UKSC 51, [95]. In the context of the named person service, Lady Hale highlighted the risk, in individual cases, of parents being given the impression that they have to accept the advice or services which they are offered and that failure to cooperate will be regarded as evidence of risk of harm. She observed: 'An assertion of such compulsion, whether express or implied, and an assessment of non-cooperation as evidence of such a risk could well amount to an interference with the right to respect for family life which would require justification under article $8(2)$.'

126 Since animals are treated as property in Scotland, a child who harmed animals might, again, be beyond the reach of the hearings system should the child or the parents prove uncooperative.

127 Children's Hearings (Scotland) Act 2011, s 67(4).

128 Police and Fire Reform (Scotland) Act 2012. 
information about individuals. In addition to details of criminal convictions, it retains 'other relevant information' and operates a Vulnerable Persons Database where 'concerns about vulnerable people', including children, are recorded.

After a period of time, individuals are generally freed from the obligation to disclose criminal convictions in job applications and the like. ${ }^{129}$ However, the Scottish rules on non-disclosure of past offences do not apply in all circumstances and so, for example, reference may be made to them in civil proceedings. In addition, disclosure may occur under a range of statutory schemes - basic, standard, enhanced and the various Protection of Vulnerable Groups schemes - run by Disclosure Scotland on behalf of the Scottish Ministers, ${ }^{130}$ when a person is applying for certain educational courses, volunteer opportunities or employment. ${ }^{131}$ For this purpose, an offence accepted or established in the context of a children's hearing is treated in the same way as a criminal conviction. Participation in these schemes is 'voluntary' in so far as the individual seeking to participate in a regulated activity applies to join the scheme. While the law governing the schemes was amended to take account of its incompatibility with Article 8 of the European Convention on Human Rights, ${ }^{132}$ it continues be a source of concern, particularly in respect of past wrong-doing by young people. ${ }^{133}$

In Scotland, there is no system of the kind, found in some other jurisdictions, for general public notification of the presence of particular kinds of offenders in the neighbourhood. ${ }^{134}$ However, in addition to the statutory schemes, there is an informal system that gives parents and guardians the opportunity to ask Police Scotland if there is any reason for them to be concerned about a person who has contact with their child. ${ }^{135}$ Disclosure of both conviction and non-conviction information is at the discretion of the police and it is conceivable that information relating to an offence referral could be revealed.

The reason for disclosure as outlined above is obvious. If a person has behaved in a way that endangered others in the past, there is concern that he or she may repeat the conduct. To put it another way, if those working or volunteering with vulnerable people were not vetted in advance, there is a risk that those least able to protect themselves might be exposed to unsuitable or dangerous individuals. Were harm to come to a vulnerable person, in the absence of vetting, there would be a public outcry. Yet, the whole disclosure process is premised on the notion of 'once bad, always bad'. Quite apart from the danger of errors in gathering (particularly non-conviction) information, the potential for disclosure of past criminality has serious implications for compliance with the requirement of the UNCRC that measures for dealing with children who offend should take into account the desirability of promoting their reintegration into society. ${ }^{136}$

129 Rehabilitation of Offenders Act 1974.

130 See the Disclosure Scotland website: <www.disclosurescotland.co.uk/index.htm>.

131 Protection of Vulnerable Groups (Scotland) Act 2007, s 95, defines 'work' very broadly.

132 Police Act 1997 and the Protection of Vulnerable Groups (Scotland) Act 2007 Remedial (No 2) Order 2015, SSI 2015/330, enacted in the wake of the Supreme Court decision in R (on the Application of T) $v$ Secretary of State for the Home Department and the Chief Constable of Greater Manchester Police [2015] AC 49.

$133 \mathrm{R}$ (on the Application of G) v Secretary of State for the Home Department and the Chief Constable of Surrey [2016] 4 WLR 94.

134 For the history of such laws in the USA, see Maureen S Hopbell, 'Balancing the Protection of Children against the Protection of Constitutional Rights: The Past, Present and Future of Megan's Law' 42 Duquesne Law Review 331 (2004).

135 Keeping Children Safe: Information Disclosure about Child Sex Offenders (Scottish Government 2015). See further, Sex Offender Community Disclosure Scheme: <www.scotland.police.uk/keep-safe/young-people/supportingchildren-and-young-people/child-protection-keeping-children-safe $>$.

136 UNCRC, Article 40(1). 
Of particular relevance for our present purpose is how information about harmful behaviour by 8 to 11 -year-olds will be treated in the future if the minimum age of criminal responsibility is raised to $12 .{ }^{137}$ In the context of ensuring that the child receives the necessary intervention and support, it was clear that there was no question of simply ignoring such behaviour. Should the same principle apply to information-gathering and disclosure? On the one hand, this would run counter to the whole notion that the child lacks the capacity to be held criminally responsible and disclosure could only obstruct the young person in securing future educational opportunities or employment, impeding his or her reintegration into society. On the other hand, it would be absurd to pretend that the behaviour had not occurred if it poses a threat to the safety of others.

The 2016 advisory group was alert to this dilemma and sought to steer a middle course. ${ }^{138}$ It recommended that information about children under 12 submitted by the police under the statutory schemes should only be disclosed in exceptional circumstances and that this should apply retrospectively to information about past criminal conduct by the under-12s. Crucially, it also recommended the introduction of independent mediation, by 'a party with expertise or knowledge in risk management', of the decision to disclose. ${ }^{139}$ It did not consider the informal scheme that relies wholly on police discretion and it would certainly be desirable that any additional safeguards should apply there too.

\section{Concluding thoughts: why the recommended reform may succeed this time}

The most recent advisory group to examine the minimum age of criminal responsibility in Scotland has recommended that it be raised from 8 to 12 years old. That recommendation comes as no surprise. An abundance of modern academic literature, supported by evidence from neuro-scientists, makes an overwhelming case for raising the age. International bodies, not least the UN Committee on the Rights of the Child, have been urging this course of action for many years. Other jurisdictions, particularly those in Europe and the rest of the developed world, have adopted ages higher - sometimes significantly higher - than 8 .

At the outset, it was suggested that there is a very real prospect that the recommendation will lead to law reform in the near future. Given that we have been here before, as recently as 2000 , that prediction may seem unduly optimistic, even foolhardy. Why might the outcome be different this time? Any law reform proposal will have the optimum chance of success if it is supported by government. Politicians have many reasons - ideological, fiscal, diplomatic, pragmatic - for supporting a particular measure and are undoubtedly influenced by how well they anticipate it being received by stakeholders and the public. As we have seen, there is widespread support amongst the legal profession, children's rights groups and academics for raising the age of criminal responsibility. What, then, of the general public?

There is little doubt that the recommendation of the 2000 advisory group suffered from unfortunate timing since it coincided with a 'tough on crime' rhetoric that reflected something of an antipathy towards children and young people, generally, and those who offended, in particular. In its Concluding Observations on the UK, in 2008, the UN Committee on the Rights of the Child expressed concern over the negative stereotyping of young

137 Parallel questions arise in respect of the taking and retention of forensic samples from 8 to 11 -year-olds and these were addressed by the 2016 advisory group: Report of the Advisory Group on the Minimum Age of Criminal Responsibility (n 3) 32-35.

138 Ibid ch 5 .

139 Ibid para 5.14 . 
people across society, particularly in the media. ${ }^{140}$ While it mentioned that concern again in its most recent Concluding Observations, ${ }^{141}$ it did not elaborate. In the interim, the Scottish government has developed various strategies designed to combat negative images of young people and has expressed its continuing commitment on that score. ${ }^{142}$ To be fair, public perceptions of young people were probably never as negative as those presented in sections of the media and, in truth, there is no single perception. ${ }^{143}$ Nonetheless, efforts to create a more positive image of children and young people may make the public more open to the idea of raising the minimum age of criminal responsibility.

Perhaps the most significant development, in Scotland, is a heightened government awareness of children's rights and a more sophisticated understanding of what is required for their implementation. ${ }^{144}$ Successive administrations have been keen to demonstrate their commitment to children's rights ${ }^{145}$ and there are examples of the fundamental principles of the UNCRC being articulated in pre-devolution legislation on family law, child protection and the children's hearings system. ${ }^{146}$ While it would be grossly premature to suggest that children's rights are as fully integrated into the Scottish legal system as they ought to be, there is a sense of making some progress towards that end.

The Scottish government's (irritating) attachment to repeating the mantra of Scotland becoming 'the best place in the world to grow up in' has been noted as have continuing problems associated with poverty. There is evidence, however, of very real governmental efforts to move beyond sloganising. That those efforts can sometimes be ill-conceived or badly executed is illustrated by the debacle surrounding the named person scheme. ${ }^{147}$ Rather less contentious have been the more comprehensive reforms designed to address the needs of the most vulnerable children. Some of these efforts have been directed at preventing offending and at diverting offenders from the formal system. ${ }^{148}$ As a result, the number of 8 to 11-year-olds referred to a children's hearing on the basis of their own alleged offending has fallen by 73 per cent in the last 5 years, with a drop from 799 cases,

140 UN Committee on the Rights of the Child, Concluding Observations: UK of Great Britain and Northern Ireland $\mathrm{CRC} / \mathrm{C} / \mathrm{GBR} / \mathrm{CO} / 4,3$ October 2008, para 25(a).

141 UN Committee on the Rights of the Child, Concluding Observations on the Fifth Periodic Report of the UK of Great Britain and Northern Ireland, CRC/C/GBR/CO/5, 3 June 2016, para 22.

142 Do the Right Thing: A Progress Report on the Scottish Government's Response to the 2008 Concluding Observations from the UN Committee on the Rights of the Child (Scottish Government 2012) 15-16.

143 Scottish Social Attitudes Survey 2009 (Scottish Government 2010): 'Adults tend to display concern both for and about young people' (para 5.3) and ' $67 \%$ [of those surveyed] agreed that "most young people in this area are responsible and well behaved”' (para 5.4).

144 In a recent appeal in Scotland's highest criminal court in a case involving a relatively rare example of prosecution of a juvenile, there was an encouraging reference from the bench to the UN Convention principles on juvenile justice. See Adam McCormick v HM Advocate [2016] HCJAC 50 [4].

145 Report on the Implementation of the UN Convention on the Rights of the Child in Scotland 1999-2007 (Scottish Executive 2007); Do the Right Thing (Scottish Government 2009); Do the Right Thing: A Progress Report (n 142).

146 Children (Scotland) Act 1995, addressing the child in the family setting, originally governed child protection and the children's hearings system as well. It was drafted with the CRC in mind and articulated some of the fundamental principles. Regulation of child protection and children's hearings is now addressed largely in other statutes, but the CRC principles remain present.

147 Christian Institute v Scottish Ministers [2016] UKSC 51.

148 Claire Lightower, David Orr and Nina Vaswani, Youth Justice in Scotland: Fixed in the Past or Fit for the Future? (Centre for Youth and Criminal Justice 2014) and Preventing Youth Offending: Getting It Right for Children and Young People (Scottish Government 2015). For a current overview, see the 'Whole System Approach to Young People who Offend' section of the Scottish Government website: <www.gov.scot/Topics/Justice/policies/youngoffending/whole-system-approach $>$. 
in 2010-2011, to 215, in 2014-2015. ${ }^{149}$ While these figures are, in large part, a product of systemic changes, the statistics can only assist in making any increase in the minimum age of criminal responsibility more publicly palatable.

The Scottish government itself has something of an incentive to make progress on raising the minimum age of criminal responsibility. When what became the Children and Young People (Scotland) Act 2014 was making its way through the Scottish Parliament, the government resisted calls to include a provision incorporating the UNCRC into Scots law, ${ }^{150}$ something that would have given that instrument the same legal status in Scotland as attaches to the European Convention on Human Rights throughout the UK. ${ }^{151}$ Instead, the Act places Scottish ministers under statutory obligations to promote awareness of children's rights; to 'keep under consideration' whether there is more they could do to give effect to the UNCRC; and to report on their progress every three years. ${ }^{152}$ For those seeking incorporation, that was a poor alternative, but the reporting obligation does present an opportunity to hold Scottish ministers to account on the issue of the minimum age of criminal responsibility. Their first report is due in 2018 and it may be that they would like to be able to report progress at that time. ${ }^{153}$

The country is currently governed by a minority SNP administration that relies on other parities for support in its legislative efforts. The 'law and order' lobby, while less vocal at the moment, is ever present. It would only take an equivalent of the Bulger case to occur in the country for the political climate to change and the momentum that has gathered behind calls for reform to vanish.

Assuming, arguendo, that the minimum age of criminal responsibility in Scotland is raised to 12 , Scots law would have reached a significant landmark in attributing criminal responsibility to children and young people in a manner that is more consistent with all the evidence on their capacity to make decisions about their behaviour. For many, this landmark would be no more than a staging post on a much longer journey. When Thomas Hammarberg, the (then) Council of Europe's Commissioner for Human Rights, expressed support for raising the age of criminal responsibility, it was 'with the aim of progressively reaching 18 '. ${ }^{154}$ In that, he was reflecting the view of many children's rights advocates: that meaningful realisation of children's rights is an incremental process. But we are getting ahead of ourselves. For the present, the focus must be on bringing to fruition the goal of raising the minimum age of criminal responsibility to 12 .

149 SCRA Annual Report 2014/2015 (n 121).

150 Education and Culture Committee of the Scottish Parliament, 11th Report, 2013 (Session 4): Stage 1 Report on the Children and Young People (Scotland) Bill, paras 27-31 <www.parliament.scot/S4_ EducationandCultureCommittee/Reports/edR-13-11w.pdf>.

151 Human Rights Act 1998.

152 Children and Young People (Scotland) Act 2014, s 1. The awkward phraseology is found in the statute. Public authorities are subject to a similar reporting requirement in respect of the steps they have taken, within their areas of responsibility, to 'secure better or further effect' of the UN Convention: 2014 Act, s 2 and Schedule 1.

153 S 1, creating the reporting obligation, was brought into force on 15 June 2015: Children and Young People (Scotland) Act 2014 (Commencement No 7) Order 2015, SSI 2016/61, Article 2(3).

154 Thomas Hammarberg, 'The Human Rights Dimension of Juvenile Justice' CommDH/Speech (2006) 12. 